Journal of Agri-Food Science and Technolgy

Journal homepage http://journal2.uad.ac.id/index.php/jafost

\title{
Physicochemical Properties of Klutuk banana Leaves \\ (Musa balbisiana Colla) Susu and Wulung Cultivars with its Potential as Antioxidant
}

\author{
Safinta Nurindra Rahmadhia ${ }^{1}$, Titisari Juwitaningtyas ${ }^{1}$ \\ ${ }^{1}$ Food Technology Study Program, Faculty of Industrial Technology, Universitas Ahmad Dahlan, \\ Yogyakarta, Indonesia \\ Corresponding Author: safinta.rahmadhia@tp.uad.ac.id
}

\section{ARTICLE INFO}

Keywords:

Klutuk banana leaf

Antioxidant

Traditional package
ABSTRACT

Banana leaf is mostly used as food packaging materials. The most often used leaf of banana trees is from Klutuk banana. Its leaf is the broadest and most durable among other banana leaf cultivars. However, the research of potential use of Klutuk banana leaf has not much done. In this research, the physical and chemical properties of Klutuk banana leaves will be observed from the very top to the bottom of the tree. Physical properties explored from Klutuk banana leaves are tensile strength, elongation, thickness, and color of the leaf. The leaf then will be extracted using methanol so that its antioxidant properties can be known. The leaf from the third petiole of Klutuk banana susu and wulung cultivars, has the best physical properties, i.e., mechanical, color, and antioxidant activity properties, and is best to use as food packaging material. The most significant activity of antioxidant is found from the first shoot of Klutuk banana susu and wulung leaf cultivars.

\section{INTRODUCTION}

Klutuk banana leaf is one of the banana leaves that mostly used because it has durable physical property and is not easy to tear among other cultivars. Besides, it has a distinctive scent when used as food packaging, which makes the packaged food scented better. Banana leaf is found to have antioxidant and antimicrobial activities. Gallic acid which is one of the antioxidants, is found in banana leaf extract based on the study done by Sahaa et al. (2013). According to Handayani and Mastuti (2014), the leaf extract of Pisang Ambon contains Phenol, 2,4-bis(1,1-dimethyl ethyl)-, which is categorized in phenolic compounds. This compound, along with E-15 heptadecenal, has the same antibacterial activities to the fraction of acetate in God leaves (Gynura segetum) based on a research done by Seow et al. (2012).

The exploration of Klutuk banana leaf, which is used as traditional food packaging material, can be seen as one of the local cultures. However, the physical and chemical properties of Klutuk banana leaf are still unknown. The objective of the research is then to 
analyze these properties on Klutuk banana leaves of susu and wulung cultivars, from the first to the last shoots of the tree. The potential of antioxidant activity will also be explored to determine which shoot or petiole has the maximum potential of antioxidants.

\section{MATERIALS AND METHODS}

\subsection{Tools and Materials}

Materials used in the research are Klutuk banana leaves of susu and wulung cultivars from the first to the fifth shoot of trees in Kebun Plasma Nutfah Pisang Yogyakarta; 2,2-diphenyl-1-picrylhydrazyl (DPPH); methanol PA; and petroleum ether. Tools used in the research are Spectrophotometer UV-VIS (Spectronic 200), Chromameter (Konika Minolta CR-400), Universal Testing Machine (Zwick ZO.5; USA), cabinet dryer, and oven.

\subsection{Research Methods}

\subsubsection{Mechanical Properties of Klutuk banana Leaf}

Mechanical analysis done in the research includes tensile strength, and elongation by using Universal Testing Machine (Zwick ZO.5; USA). Each analysis was done in three repetitions.

\subsubsection{Thickness of Klutuk banana Leaf}

Thickness analysis of Klutuk banana leaf used digital micrometer with a precise of $0.0001 \mathrm{~mm}$. The measurement is done randomly at 5 different points on the leaf with three times repetitions.

\subsubsection{Color of Klutuk banana Leaf}

Color analysis of Klutuk banana leaf used chromameter (Konika Minolta CR400). The color measured on the screen as L score for lightness, a score for appearance, and b score as blueness measurements. The measurements are done in three times repetitions.

\subsubsection{Fat Content of Klutuk banana Leaf}

Fat content analysis is done by using method of AOAC (2006). The measurements are done in three times repetitions.

\subsubsection{Extraction of Klutuk banana Leaf}

The extraction of Klutuk banana leaf is done by using a method described in Madikizela et al. (2014) with some modification. Klutuk banana leaves of Susu dan wulung cultivar from the first to fifth shoots were washed by tap water and cut in uniform-sized pieces. Those pieces were then dried in a cabinet dryer for 12 hours. The dried leaves then will be mashed up by using a blender and sifted with a 60 -mesh strainer. The extraction is done based on the maceration method. The powder of dried leaves is macerated by using $80 \%$ ethanol for 48 hours, then filtered by using a filter paper. The solvent evaporated by using an oven.

\subsubsection{Antioxidant Activity of Klutuk banana Leaf}

Antioxidant activity of Klutuk banana leaf will be analyzed with 2,2-diphenyl1-picrylhydrazyl (DPPH) by using a method in Williams et al. (1995). 


\section{RESULT AND DISCUSSIONS}

\subsection{Mechanical Properties of of Klutuk banana Leaf}

Mechanical properties of Klutuk banana leaf of susu dan wulung cultivar observed in the research are tensile strength and elongation of the leaf. The observation is done with eyes' positions parallel to the fiber of leaf. Based on Table 1, the older the age of the leaves, then the stronger the tensile strength and flexibility. The old leaves are indicated by the lower position of the petiole of Klutuk banana leaf. The higher the value of tensile strength indicates the more sturdy the leaf is. Meanwhile, less value of elongation indicates the more flexible the leaf is.

Beside affected by the age of the leaf, the tensile strength of Klutuk banana leaf is also affected by its cultivar. Klutuk banana leaves of wulung cultivar have higher tensile strength than leaves of susu cultivar. Klutuk banana of wulung cultivar leaves are stronger and more sturdy than leaves of susu cultivar.

Table 1. Mechanical properties of Klutuk banana leaves of Susu and wulung cultivars.

\begin{tabular}{ccccc}
\hline & \multicolumn{2}{c}{$\begin{array}{c}\text { Klutuk banana leaves of } \\
\text { susu cultivar }\end{array}$} & \multicolumn{2}{c}{$\begin{array}{c}\text { Klutuk banana leaves of } \\
\text { wulung cultivar }\end{array}$} \\
\cline { 2 - 5 } n-th leaf & $\begin{array}{c}\text { Tensile } \\
\text { Strength } \\
\left(\mathrm{N} / \mathrm{mm}^{2}\right)\end{array}$ & $\begin{array}{c}\text { Elongation } \\
(\%)\end{array}$ & $\begin{array}{c}\text { Tensile } \\
\text { Strength } \\
\left(\mathrm{N} / \mathrm{mm}^{2}\right)\end{array}$ & $\begin{array}{c}\text { Elongation } \\
(\%)\end{array}$ \\
\hline 1 & 4.6873 & 4.3749 & 6.9264 & 4.3874 \\
2 & 6.0691 & 4.1584 & 8.3489 & 4.3589 \\
3 & 6.4542 & 3.8571 & 9.4103 & 3.9877 \\
4 & 7.9621 & 3.5026 & 10.8681 & 3.9560 \\
5 & 9.7903 & 2.9121 & 12.2249 & 3.6311 \\
\hline
\end{tabular}

The high amount of water content and the sturdy texture of the leaf are in line with the increase of tensile strength on Klutuk banana leaves of susu and wulung cultivars. The thickness difference of leaves may happen due to the difference in their water content. The higher the water content of a leaf, then the leaf is more rigid due to its cell walls, which pushed by water (Badar, 2006).

\subsection{Thickness of Klutuk banana Leaf}

The thickness of leaves is one of the physical properties, which is essential to be analyzed due to its function as food packaging. The measurement of Klutuk banana leaf thickness is done while the leaves are still fresh. Based on Table 2, Klutuk banana leaves from the first to the fifth shoots have no significant difference in thickness.

Table 2. The thickness of Klutuk banana leaves of Susu and wulung cultivars.

\begin{tabular}{ccc}
\hline n-th & \multicolumn{2}{c}{ Thickness (mm) } \\
\cline { 2 - 3 } Leaf & $\begin{array}{c}\text { Leaves of } \\
\text { susu } \text { cultivar }\end{array}$ & $\begin{array}{c}\text { Leaves of } \\
\text { wulung cultivar }\end{array}$ \\
\hline 1 & 0.346 & 0.322 \\
2 & 0.265 & 0.343 \\
3 & 0.342 & 0.325 \\
4 & 0.305 & 0.349 \\
5 & 0.324 & 0.389 \\
\hline
\end{tabular}


Treshow (1970) mentioned that the low intensity of light makes plants have a bigger and thinner size of leaves, bigger stomata, more spaces between cells, and thinner epiderm cells. It happens as one of the adaptations made by leaves from various plants. Leaves will have anatomical and morphological changes like increasing the number of $b$ chlorophylls, the area of the leaf, number of cuticles, wax layers, leaf feathers (trichomes), and level of anthocyanin pigment while decreasing the leaf thickness (Karyati et al., 2017).

\subsection{Color of Klutuk banana Leaf}

Color measurement of Klutuk banana leaves of susu and wulung cultivars are done on the outer side of the leaf. The result of color measurement is shown in Table 3 with three measurement parameters, i.e., lightness (L), appearance $(a)$, and blueness $(b)$. The positive value of $\mathrm{L}$ means light, while the negative one means dark. The positive value of $a$ indicates the red color, while the negative indicates green color. The positive value of $b$ indicates the yellow color, while the negative indicates the blue color.

Based on Table 3, the value of L on Klutuk banana leaves of susu and wulung cultivars from the first to fifth shoots have an insignificant difference. However, susu cultivar has a lighter color than leaves of wulung cultivar from its bigger value of L. The value of $a$ on leaves of Susu cultivar is less than wulung cultivar, so the Klutuk banana leaves of susu cultivar has brighter green in color. Moreover, the older the age of the leaf indicates brighter green in color from the result of measurement of $a$ value. Meanwhile, the positive value of $b$ indicates the yellow color of the leaf. The bigger the value of $b$ means that the leaf has brighter yellow in color. Klutuk banana leaves of wulung cultivar have a lesser value of $b$ than leaves of Susu cultivar. This indicates that wulung cultivar has leaves with a darker yellow color.

Table 3. Color of Klutuk banana leaves of susu and wulung cultivars.

\begin{tabular}{ccccccc}
\hline \multirow{2}{*}{$\begin{array}{c}\text { n-th } \\
\text { Leaf }\end{array}$} & \multicolumn{3}{c}{ Leaves of susu cultivar } & \multicolumn{3}{c}{ Leaves of wulung cultivar } \\
\cline { 2 - 7 } & $\mathrm{L}$ & $A$ & $b$ & $\mathrm{~L}$ & $a$ & $b$ \\
\hline 1 & $44.31^{\mathrm{a}}$ & $-17.79^{\mathrm{a}}$ & $30.90^{\mathrm{a}}$ & $38.82^{\mathrm{a}}$ & $-14.51^{\mathrm{a}}$ & $22.07^{\mathrm{a}}$ \\
2 & $42.74^{\mathrm{a}}$ & $-16.18^{\mathrm{ab}}$ & $26.77^{\mathrm{a}}$ & $38.19^{\mathrm{a}}$ & $-11.90^{\mathrm{ab}}$ & $17.34^{\mathrm{a}}$ \\
3 & $42.48^{\mathrm{a}}$ & $-15.67^{\mathrm{ab}}$ & $24.37^{\mathrm{a}}$ & $37.75^{\mathrm{a}}$ & $-11.30^{\mathrm{ab}}$ & $17.21^{\mathrm{a}}$ \\
4 & $43.30^{\mathrm{a}}$ & $-15.92^{\mathrm{b}}$ & $25.40^{\mathrm{a}}$ & $37.08^{\mathrm{a}}$ & $-10.09^{\mathrm{b}}$ & $14.79^{\mathrm{a}}$ \\
5 & $45.44^{\mathrm{a}}$ & $-16.58^{\mathrm{b}}$ & $28.25^{\mathrm{a}}$ & $38.58^{\mathrm{a}}$ & $-9.63^{\mathrm{b}}$ & $16.33^{\mathrm{a}}$ \\
\hline
\end{tabular}

The letter symbol shows the significant difference of Klutuk banana leaves of susu and wulung cultivars $(p<0,05)$ on the same column.

Based on Table 3, different cultivars will affect the overall color of the leaf. Gogahu et al. (2016) stated that the total concentration of chlorophyll on 3-month-old crotons from different cultivars have an insignificant difference. Meanwhile, when the crotons reached the age of 8 months, the concentration of chlorophyll showed a significant difference between cultivars. The total concentration of chlorophyll caused the different colors of the leaf in general.

The color difference in leaves is not only influenced by the total chlorophyll pigment, but all types of pigment will affect the color appearance of the leaf. Some types of theses pigments are carotene, anthocyanin, xanthophyll, and etc. (Ogunwenmo et al., 2007). The color difference of Klutuk banana leaves of susu and wulung cultivars is not only influenced by the type of the leaf but also the pigment concentration of each cultivar 
leaves. Besides, the age of Klutuk banana leaf also roles in the leaf color difference of both different cultivars.

\subsection{Fat Content of Klutuk banana Leaf}

The measurement of fat content from leaves use the Soxhlet method. The measured data are shown in Table 4. It shows that the older the age of the leaf, its fat content will be increased on both cultivars. However, the results are statistically insignificant in the difference between the first to fifth shoots.

Table 4. The fat content of Klutuk banana leaves of susu and wulung cultivars

\begin{tabular}{ccc}
\hline & \multicolumn{2}{c}{ Fat content $(\%)$} \\
\cline { 2 - 3 } Leaf & Leaves of susu cultivar & Leaves of wulung cultivar \\
\hline 1 & $8.73^{\mathrm{a}}$ & $8.59^{\mathrm{a}}$ \\
2 & $8.91^{\mathrm{a}}$ & $8.89^{\mathrm{a}}$ \\
3 & $8.99^{\mathrm{a}}$ & $9.58^{\mathrm{a}}$ \\
4 & $9.24^{\mathrm{a}}$ & $9.49^{\mathrm{a}}$ \\
5 & $9.61^{\mathrm{a}}$ & $10.05^{\mathrm{a}}$ \\
\hline
\end{tabular}

The letter symbol shows the significant difference of Klutuk banana leaves of susu and wulung cultivars $(p<0,05)$ on the same column.

There is a shining layer that covers the surface of the leaf on banana leaves. It is called by wax layer or cuticle. The surface of the plant is covered by polyester lipid layer consisted of cutin, which contains fatty acid compounds such as palmitic acid and stearate (Aharoni et al., 2004). Fitriani (2017) obtained the result of fat content in Klutuk banana leaves as $18.88 \%$ on her experiment. This indicates that the cultivar and the origin of the leaf affects its content of fat.

\subsection{Antioxidant Activity of Klutuk banana Leaf}

Antioxidant activity of Klutuk banana leaves extract of susu and wulung cultivars was analyzed by using spectrophotometer Uv-Vis on the wave length of $515 \mathrm{~nm}$. The concentration of the extract analyzed is $1000 \mathrm{ppm}$. The antioxidant level is represented in Table 5.Based on the measurement, the antioxidant activity of Klutuk banana leaf is influenced by the cultivar and the age of the leaf. The biggest antioxidant activity is found on the first shoot, while the lowest is found on the fifth shoot. Hence, the older the age of the leaf is, then its antioxidant activity will be lower.

Table 5. Antioxidant activity of Klutuk banana leaves of susu and wulung cultivars on $1000 \mathrm{ppm}$ concentration

\begin{tabular}{ccc}
\hline \multirow{2}{*}{ n-th Leaf } & \multicolumn{2}{c}{ RSA $(\%)$} \\
\cline { 2 - 3 } & Leaves of susu cultivar & Leaves of wulung cultivar \\
\hline 1 & $40.55^{\mathrm{c}}$ & $44.14^{\mathrm{c}}$ \\
2 & $22.70^{\mathrm{a}}$ & $35.75^{\mathrm{a}}$ \\
3 & $38.26^{\mathrm{b}}$ & $38.48^{\mathrm{b}}$ \\
4 & $45.96^{\mathrm{b}}$ & $28.79^{\mathrm{b}}$ \\
5 & $30.17^{\mathrm{a}}$ & $29.14^{\mathrm{a}}$ \\
\hline
\end{tabular}

The letter symbol shows the significant difference of Klutuk banana leaves of Susu and wulung cultivars $(p<0,05)$ on the same column. 
Wojdyto et al. (2007) mentioned that a drying process that takes more than 7 hours would denature the antioxidant compound in a material. Based on Sagrin et al. (2013) research, the drying temperature will significantly affect its antioxidant level, the total content of phenolics, water activity, color, and rehydration of a banana leaf. The suitable temperature for drying is $50^{\circ} \mathrm{C}$. The drying process is done for 12 hours on the temperature of $50^{\circ} \mathrm{C}$. This duration of drying is chosen because if it takes less than 12 hours, then the leaves are not completely dried, and it will be hard to be smashed into powder. Fitriani (2016), in her research, mentioned that the antioxidant activity of Klutuk banana leaves extract is $4.74 \% \mathrm{RSA}$ on the concentration of $0.01 \mathrm{~g} / 100 \mathrm{ml}$. The antioxidant activity of Klutuk banana leaves also depends on its origin, which means the tree used in the research.

The capability of free radical scavenging is profoundly influenced by the hydroxyl group $(\mathrm{OH})$ on the phenolic compounds (Nakiboglu et al., 2007). More hydroxyl group $(\mathrm{OH})$ substituted in a molecule, then its free radical scavenging activity will be higher because the number of donated hydrogen atoms is also increased (Yu Lin et al., 2009).

\section{CONCLUSIONS}

From the research that has been done, it can be concluded that the best Klutuk banana leaf of susu and wulung cultivars as a food packaging material is in the third leaf stalk (petiole) based on its mechanical properties, color, and antioxidant activity. The highest antioxidant activity is found in the first leaf bud (shoot) of Klutuk banana leaves of susu and wulung cultivars.

\section{ACKNOWLEDGMENT}

Authors would like to express gratitude to Lembaga Penelitian dan Pengabdian Kepada Masyarakat (LPPM) Universitas Ahmad Dahlan Indonesia who has granted and funded the research through Penelitian Dosen Pemula (PDP) program.

\section{BIBLIOGRAPHY}

Aharoni, A., Shital, D., Reinhard, J., Eveline, T., Gert, W-A., dan Andy, P. (2004). The SHINE Clade of AP2 Domain Transcription Factors Activates Wax Biosynthesis, Alters Cuticle Properties, and Confers Drought Tolerance when Overexpressed in Arabidopsis. The Plant Cell. Vol 16: 2463 - 2480.

Badar, A.A. (2006). Karakterisasi Sifat Fisiko Kimia dan Mekanik Daun Patat (Phrynium capitatum) sebagai Bahan Kemasan. Institut Pertanian Bogor, Bogor.

Fitriani, V. (2016). Tesis, Karakter Fisik dan Kimia serta Identifikasi Senyawa Bioaktif dari Daun Klutuk banana (Musa bracycarpa) Sebagai Bahan Pengemas Makanan. Fakultas Teknologi Pertanian, Universitas Gadjah Mada Yogyakarta.

Gogahu, Y., Ai, N.S., dan Siahaan, P. (2016). Konsentrasi Klorofil pada Beberapa Varietas Tanaman Puring (Codiaeum varigatum L). Jurnal MIPA Unstrat, 5(2): 76-80.

Handayani, R. dan Mastuti, T.S. (2014). Senyawa Penyusun Ekstrak N-Heksana Dari Daun Pisang Batu, Kepok dan Ambon Hasil Distilasi Air. Prosiding Seminar Nasional Bioteknologi, Universitas Surabaya.

Karyati., Ransun, J.R., dan Syafrudin, M. (2017). Karakteristik Morfologis dan Anatomi Daun Tumbuhan Herba Pada paparan Cahaya Berbeda di Hutan Pendidikan Fakultas Kehutanan Universitas Mulawarman. Jurnal Agrofor, 16 (2): 243 - 256.

Nakiboglu, M., Urek, R.O., Kayali, H.A., dan Tarhan. (2007). Antioxidant Capacities of Endemic Sideritis Sipylea and Origanum Sipyleum From Turkey. Journal of Food Chemistry, 104: 630-635. 
Ogunwenmo, K.O., Idowu, O.A., Innocent, C., Esan, E.B., dan Oyelana, O.A. (2007). Cultivars of (Codiaeum varigatum L) Blume (Eophurbiacae) Show Variabelity In Phytochemical and Chytological Chalateristics. African Journal of Biotechnology, 6(20): 2400-2405.

Sagrin, M.S., dan Chong, G.H. (2013). Effect of Drying Temperature on The Chemical and Physical Properties of Musa acuminata Colla (AAA Group) Leaves. Journal Industrial Crops and Products, 45: 430-434.

Sahaa, R.K., Srijan, A., Syed, S.H.S., dan Priyanka, R. (2013). Medicinal Activities of The Leaves of Musa sapientum var. Sylvesteris in vitro. Asian Pacific Journal of Tropical Biomedicine, 3: 476-482.

Sayuti, K. Dan Yenrina, R. (2015). Antioksidan, Alami dan Sintetik. Padang: Andalas University Press.

Seow, L.J., Beh, H.K., Ibrahim, P., Sadikun, A. dan Asmawi, Z. (2012). Antimicrobial Activity of Gynura segetum's Leaf Extracts and Its Active Fractions. Tang International Journal of Genuine Traditional Medicine, 2: 115-123.

Treshow, M.L. (1970). Environtment and Plant response. Mc Graw Hill Company, new York.

Williams, W.B., Cuvelier, M.E., dan Berset, C. (1995). Use of Free Radical Method to Evaluate Antioxidant Activity. Lebensm-Wiss-U-Technology, 28: 25-30.

Wojdyto, A., Figiel, A., dan Oszmianski, J. (2007). Influence of Temperature and Time of Apple Drying on Phenolic Compounds Content and Their Antioxidant Activity. Polish Journal Food Nutrition Science, 57: 601-605.

Yu Lin, H., Kuo, Y.H., Lin, Y.L., dan Chiang, W. (2009). Antioxidative Effect and Active Components From Leaves of Lotus (Nelumbo nucifera). Journal of Agricultural and Food Chemistry, 57: 6623-6629. 


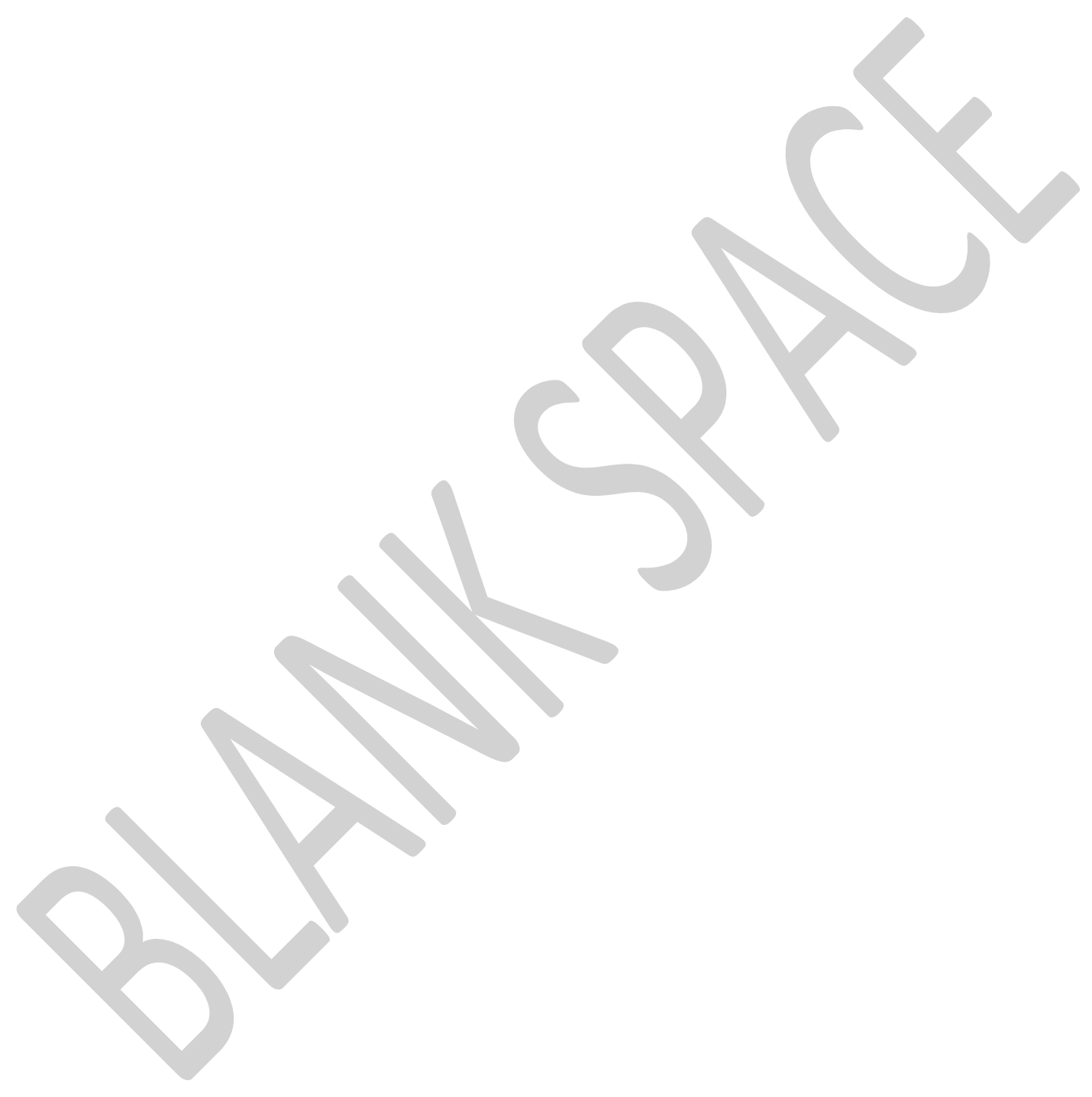

